\title{
A recombinant rabies vaccine expressing the trimeric form of the glycoprotein confers enhanced immunogenicity and protection in outbred mice
}

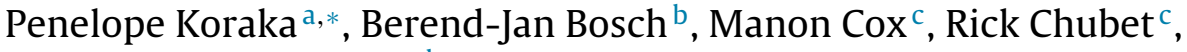 \\ Geert van Amerongen $^{\mathrm{a}, \mathrm{d}}$, Karen Lövgren-Bengtsson ${ }^{\mathrm{e}}$, Byron E.E. Martina ${ }^{\mathrm{a}}$, \\ Jouke Roose $^{\mathrm{a}}$, Peter J.M. Rottier ${ }^{\mathrm{b}}$, Albert D.M.E. Osterhaus ${ }^{\mathrm{a}}$ \\ a Department of Viroscience, Erasmus Medical Centre, PO Box 2040, 3000 CA Rotterdam The Netherlands \\ ${ }^{\mathrm{b}}$ Virology Division, Department of Infectious Diseases \& Immunology, Faculty of Veterinary Medicine, Utrecht University, $3508 T D$ Utrecht, The Netherlands \\ c Protein Sciences Corp, 1000 Research Parkway, Meriden, CT 06450-7159, USA \\ d Institute for Translational Immunology, PO Box 450, 3720 AL Bilthoven, The Netherlands \\ e Novavax AB, Kungsgatan 109, SE-753 18 Uppsala, Sweeden
}

\section{A R T I C L E I N F O}

\section{Article history:}

Received 22 April 2014

Received in revised form 2 June 2014

Accepted 11 June 2014

Available online 21 June 2014

\section{Keywords:}

Rabies

Vaccine

Glycoprotein G

Matrix- $\mathrm{M}^{\mathrm{TM}}$

\begin{abstract}
A B S T R A C T
Rabies is a disease characterized by an invariably lethal encephalitis of viral origin that can be controlled by preventive vaccination programs of wildlife, domestic animals and humans in areas with a high risk of exposure. Currently available vaccines are expensive, cumbersome to produce and require intensive immunization and booster schemes to induce and maintain protective immunity. In the present study, we describe the development of candidate recombinant subunit rabies vaccines based on the glycoprotein $G$ of the prototype rabies virus (RABV-G) expressed either as a monomer (RABV-mG) or in its native trimeric configuration (RABV-tG), with or without Matrix-M $\mathrm{M}^{\mathrm{TM}}$ adjuvant. Immunogenicity and protective efficacy of the respective candidate vaccines were tested in outbred NIH Swiss albino mice. The RABV-tG candidate vaccine proved to be superior to the RABV-mG vaccine candidate both in terms of immunogenicity and efficacy. The relatively poor immunogenicity of the RABV-mG vaccine candidate was greatly improved by the addition of the adjuvant. A single, low dose of RABV-tG in combination with Matrix-M ${ }^{\mathrm{TM}}$ induced high levels of high avidity neutralizing antibodies and protected all mice against challenge with a lethal dose of RABV. Consequently RABV-tG used in combination with Matrix- $\mathrm{M}^{\mathrm{TM}}$ is a promising vaccine candidate that overcomes the limitations of currently used vaccines.
\end{abstract}

(c) 2014 Elsevier Ltd. All rights reserved.

\section{Introduction}

Rabies encephalitis can be caused by any of the members of the lyssavirus genus of the family Rhabdoviridae including the prototype rabies virus (RABV). It accounts for more than 55,000 reported deaths per year, mostly among children in the developing world [1]. Productive infection of humans with any of the lyssaviruses will lead to $100 \%$ lethal encephalitis. RABV and other lyssaviruses are transmitted via the bite or scratch of an infected animal. Essentially all mammals are susceptible to rabies and can transmit the virus. Human and animal vaccines against RABV are available, allowing effective rabies control, based on extensive vaccination programs of wildlife species and usually mandatory

\footnotetext{
* Corresponding author. Tel.: +31 10 7044279; fax: +31 107044760.

E-mail address: p.koraka@erasmusmc.nl (P. Koraka).
}

vaccination programs for domestic carnivores. For humans, preexposure immunization is recommended for travellers to endemic areas and professionals who may be occupationally exposed to the virus or virus-infected animals. Despite the effectiveness of existing vaccines, they are among the most expensive vaccines with a relatively poor immunogenicity, since protection is conferred after several immunizations with high antigen doses. Most commonly three doses are required to confer protective immunity and booster vaccinations are necessary to ensure long term protection. Therefore, the vaccine is considered expensive and often rather used for post exposure prophylaxis (PEP) than for prevention. Although PEP can protect vaccine recipients from clinical rabies and death, it should be given promptly (within 24 to $48 \mathrm{~h}$ post exposure) [2]. However, in endemic areas PEP is often not available when needed and preventive vaccination coverage are low. Therefore more immunogenic and cheaper rabies vaccines are urgently needed. 
In the recent years several approaches have been explored to improve immunogenicity and reduce cost of existing vaccines using novel production and presentation platforms. Of these the development of DNA and recombinant protein vaccines are among the most promising approaches (reviewed in [3]). The glycoprotein $\mathrm{G}$ of RABV (RABV-G) assembles in the membrane envelope of the virion in the form of homotrimers, which harbour the major antigenic determinants of the virus [4]. Therefore, most of the recombinant candidate vaccines described today, are based on RABV-G protein produced with several different expression systems [5-9]. Some of these candidates were shown to be immunogenic in mice, but none have so far been registered for human or animal use. In the present paper we describe the enhanced immunogenicity and protective efficacy of a novel recombinant RABV-G vaccine candidate based on the trimeric form of the RABV-G protein (RABV-tG) expressed in HEK293T cells. A similar approach has been shown to be effective in the development of candidate vaccines against other viral infections such as influenza [10]. The RABV-tG based candidate vaccine performed superior to a predominantly monomeric form of RABV-G recombinant protein (RABV-mG) produced in insect cells. Furthermore, we show that the addition of a potent adjuvant to these vaccine preparations increases the immunogenicity of the candidate vaccine, resulting in dose sparing and fewer immunizations required to confer complete protection from rabies in an outbred mouse model. Collectively these data hold promise for the development of novel generations of effective, cheap and safe vaccines against rabies.

\section{Materials and methods}

\subsection{Construction of candidate vaccines}

\subsection{1. $R A B V-m G$}

A 1518 bp DNA containing the RABV-G ectodomain with transmembrane domain and C-terminus (accession number: M13215) was amplified by PCR and cloned into a baculovirus transfer vector. Spodoptera frugiperda cells were infected with the recombinant baculovirus and harvested approximately $55 \mathrm{~h}$ post infection with a cell viability of approximately $75 \%$. The monomeric protein was purified by extracting the cells using mild detergent conditions, followed by ion-exchange and lentil lectin affinity chromatography.

\subsection{2. $R A B V-t G$}

A human codon-optimized sequence encoding the RABV-G ectodomain (amino acids [aa] 20 to 455) of RABV strain Pasteur (Accession number: M13215) was synthesized (Base Clear, Leiden, The Netherlands) and cloned into a derivative of expression plasmid pS1-Ig [11] for expression in HEK293T cells. The G gene was preceded by a sequence encoding an N-terminal CD5 signal peptide and followed by sequences encoding a 7-aa long linker (LIGGGGI), an artificial GCN4-based trimerization domain (GCN4-pII) and a Strep tag for affinity purification (IBA GmbH) as described recently [10]. The strep-tagged RABV-tG was expressed and purified following a protocol described before [10]. In short, HEK293T cells were transfected with the RABV-tG expression plasmid using polyethyleneimine. After $6 \mathrm{~h}$ of incubation, the transfection medium was replaced by 293 SFM II expression medium (Invitrogen) supplemented with sodium bicarbonate $(3.7 \mathrm{~g} / \mathrm{l})$, glucose $(2.0 \mathrm{~g} / \mathrm{l})$, Primatone RL-UF (3.0 g/l), penicillin (100 units/ml), streptomycin $(100 \mu \mathrm{g} / \mathrm{ml})$, glutaMAX (Gibco), and 1.5\% dimethyl sulfoxide (DMSO). Tissue culture supernatants were harvested 5 to 6 days post transfection, and RABV-tG protein was purified from the culture medium using Strep-Tactin affinity chromatography (IBA $\mathrm{GmbH}$ ). RABV-tG protein expression and purification were confirmed by Western blotting using a Strep-Tactin-horseradish peroxidase conjugate (IBA GmbH) (data not shown) and SDSPAGE analysis. Protein concentrations were measured using the NanoDrop ND-1000 spectrophotometer (Nanodrop technologies, Wilmington).

\subsection{SDS PAGE gel and Western blotting}

Samples were separated on 10\% SDS-PAGE gel in a MiniPROTEAN gel electrophoresis system (Bio-Rad). Gels were transferred to a $0.22 \mu \mathrm{m}$ nitrocellulose membrane (Li-COR) at $250 \mathrm{~mA}$ overnight (Mini-PROTEAN; Bio-Rad). Blots were saturated with 5\% nonfat dried milk in PBS and washed three times with PBS containing $0.1 \%$ Tween-20. Blots were subsequently incubated with monoclonal antibodies recognizing a RABV-G linear (clone 2-22C5) or conformational (clone 1-11-D6) epitope [12] or mouse IgG1 (isotype control) and stained with rabbit anti-mouse IRDye 800 (Li-COR).

\subsection{Immunization and challenge of mice}

Groups of ten 3-week old outbred NIH Swiss-albino mice (Harlan Laboratories, Boxmeer, The Netherlands) were immunized with different doses of the monomeric or trimeric vaccine candidates with or without Matrix- $\mathrm{M}^{\mathrm{TM}}$ (Table 1 ). The doses used in this experiment were standardised based on the commercial RABV vaccine. Four weeks later (D28) mice were boosted with the same vaccine formulations, except for Groups no. 7 and no. 14 which received a single adjuvanted dose. One group of mice was immunized twice with a commercially available human RABV vaccine (Sanofi Pasteur, Lyon, France) using $1 / 10$ th of a human dose per mouse (containing approx. $1 \mu \mathrm{g}$ of $\mathrm{G}$ protein; data not shown). Other control groups received either PBS alone or Matrix- $\mathrm{M}^{\mathrm{TM}}$ alone (Table 1 ). Immunizations were given intra-muscularly in $100 \mu \mathrm{l}$ volumes. All mice were challenged intracranially with $10 \mu$ l volumes containing $10^{4} \mathrm{TCID}_{50}$ of CVS-11 three weeks after booster (D49). Challenge dose was chosen based on preliminary experiments in our lab that showed this dose led to $100 \%$ mortality of infected mice. Intracranial inoculation was chosen based on the generally accepted $\mathrm{NIH}$ potency test for rabies vaccines [13]. All mice that survived challenge were euthanized at day 28 post challenge (D77). Animals were kept in isolator cages after challenge, in a $12 \mathrm{~h}$ day-night cycle and were given water and food ad libitum. All animal experiments were carried out in accordance with institutional guidelines for animal welfare and were approved by the animal ethics committee of the Erasmus Medical Centre in compliance with Dutch law.

\subsection{Serology}

Blood was collected from mice by oblique superficial cut of the tail on day $0,28,49$ and 77 . Serum was separated after centrifugation at $3000 \mathrm{rpm}$ for $10 \mathrm{~min}$, heat-inactivated at $56^{\circ} \mathrm{C}$ for $30 \mathrm{~min}$ and stored at $-20^{\circ} \mathrm{C}$ until use. High-binding ELISA plates (Costar, Zwijndrecht, The Netherlands) were coated with RABV antigen (whole virus-BPL inactivated) overnight at $4{ }^{\circ} \mathrm{C}$, washed thoroughly with PBS containing $0.05 \%$ Tween-20 (PBS-T) to remove unbound antigen and blocked with ELISA buffer $(0.5 \%$ skimmed milk, $3 \% \mathrm{NaCl}$ in PBS) for $1 \mathrm{~h}$ at $37^{\circ} \mathrm{C}$. Mouse serum was diluted 1:100 in ELISA buffer and applied to the plates for $1 \mathrm{~h}$ at $37^{\circ} \mathrm{C}$. After thorough washing with PBS-T the secondary antibody (protein-A HRPO; Zymed, Bleiswijk, The Netherlands) was applied for $1 \mathrm{~h}$ at $37^{\circ} \mathrm{C}$. Plates were developed with tetramethylbenzidine and absorption was measured at $450 \mathrm{~nm}$ using a $620 \mathrm{~nm}$ reference filter. Avidity ELISA was performed identical to the antibody ELISA with the exception that antibodies were eluted with $6 \mathrm{M}$ urea for $5 \mathrm{~min}$ before addition of secondary antibody. Virus neutralizing antibodies (VNA) 
Table 1

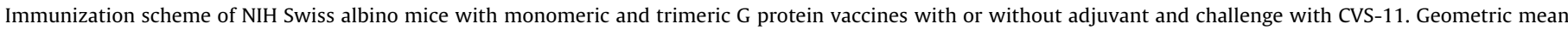

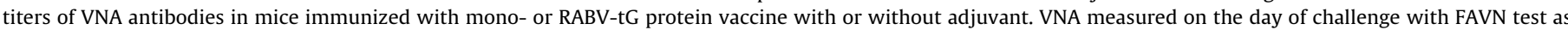
described in Section 2.

\begin{tabular}{|c|c|c|c|c|c|c|c|}
\hline \multirow{2}{*}{$\frac{\text { Group }(n=10)}{1}$} & \multirow{2}{*}{$\begin{array}{l}\text { Antigen } \\
10 \mu \mathrm{g} \text { of RABV-mG }\end{array}$} & \multirow{2}{*}{$\begin{array}{l}\text { Adjuvant } \\
\text { None }\end{array}$} & \multicolumn{2}{|c|}{ Vaccination } & \multirow{2}{*}{$\begin{array}{l}\text { Challenge } \\
D=49\end{array}$} & \multirow{2}{*}{$\begin{array}{l}\text { VNA GMT (IU/ml) } \\
6.35\end{array}$} & \multirow{2}{*}{$\begin{array}{c}\text { Survivors (\%) } \\
\mathbf{8 0}\end{array}$} \\
\hline & & & $D=0$ & $D=28$ & & & \\
\hline 2 & $3 \mu \mathrm{g}$ of RABV-mG & None & $D=0$ & $D=28$ & $D=49$ & 0.79 & 60 \\
\hline 3 & $1 \mu \mathrm{g}$ of RABV-mG & None & $D=0$ & $D=28$ & $D=49$ & 0.18 & 10 \\
\hline 4 & $10 \mu \mathrm{g}$ of RABV-mG & Matrix-M ${ }^{\mathrm{TM}}$ & $D=0$ & $D=28$ & $D=49$ & 13.77 & 90 \\
\hline 5 & $3 \mu \mathrm{g}$ of RABV-mG & Matrix-M $\mathrm{M}^{\mathrm{TM}}$ & $D=0$ & $D=28$ & $D=49$ & 13.77 & 80 \\
\hline 6 & $1 \mu \mathrm{g}$ of $\mathrm{RABV}-\mathrm{mG}$ & Matrix-M $\mathrm{M}^{\mathrm{TM}}$ & $D=0$ & $D=28$ & $D=49$ & 11.67 & 80 \\
\hline 7 & $3 \mu \mathrm{g}$ of $\mathrm{RABV}-\mathrm{mG}$ & Matrix-M ${ }^{\mathrm{TM}}$ & $D=0$ & & $D=49$ & 7.92 & 80 \\
\hline 8 & $10 \mu \mathrm{g}$ of RABV-tG & None & $D=0$ & $D=28$ & $D=49$ & 11.35 & 100 \\
\hline 9 & $3 \mu \mathrm{g}$ of RABV-tG & None & $D=0$ & $D=28$ & $D=49$ & 9.61 & 100 \\
\hline 10 & $1 \mu \mathrm{g}$ of RABV-tG & None & $D=0$ & $D=28$ & $D=49$ & 1.99 & 100 \\
\hline 11 & $10 \mu \mathrm{g}$ of RABV-tG & Matrix-M $\mathrm{M}^{\mathrm{TM}}$ & $D=0$ & $D=28$ & $D=49$ & 13.03 & 100 \\
\hline 12 & $3 \mu \mathrm{g}$ of RABV-tG & Matrix-M $\mathrm{M}^{\mathrm{TM}}$ & $D=0$ & $D=28$ & $D=49$ & 13.40 & 100 \\
\hline 13 & $1 \mu \mathrm{g}$ of RABV-tG & Matrix-M $\mathrm{M}^{\mathrm{TM}}$ & $D=0$ & $D=28$ & $D=49$ & 12.56 & 100 \\
\hline 14 & $3 \mu \mathrm{g}$ of RABV-tG & Matrix--M ${ }^{\mathrm{TM}}$ & $D=0$ & & $D=49$ & 10.16 & 100 \\
\hline 15 & Commercial vaccine & None & $D=0$ & $D=28$ & $D=49$ & 6.59 & 100 \\
\hline 16 & PBS & None & $D=0$ & $D=28$ & $D=49$ & 0.06 & $\mathbf{0}$ \\
\hline 17 & PBS & Matrix- $\mathrm{M}^{\mathrm{TM}}$ & $D=0$ & $D=28$ & $D=49$ & 0.06 & $\mathbf{0}$ \\
\hline
\end{tabular}

were determined with the fluorescent antibody virus neutralization assay as previously described [14].

\subsection{Virus detection}

Brains were collected from all animals after challenge, homogenized in $1 \mathrm{ml}$ of medium containing $10 \%$ antibiotics and stored at $-80^{\circ} \mathrm{C}$ until use. Real-time PCR for the detection of viral RNA was performed with the TaqMan ${ }^{\circledR}$ Fast-virus one-step master mix (Applied Biosystems, Nieuwerkerk aan den IJssel, The Netherlands) and primers/probe combinations previously described [15]. RNA copy-numbers were quantified using a standard curve of in-vitro transcribed RNA of known quantities. Infectious virus titers were determined in the brains of challenged mice on BHK-21-C13 cells as previously described [16].

\subsection{Statistical analysis}

Survival curves were made with the Kaplan-Meier method and analysed with a two-tailed logrank test (Graph Pad version 4). Virus titres were calculated with the Kärber-Kaplan method [17]. Viral and antibody titers were compared with a two-tailed, nonparametric Mann-Whitney test (Graph Pad version 4).

\section{Results}

\subsection{Production of recombinant $R A B V-G$ proteins}

Monomeric and trimeric RABV-G proteins were characterized by Western blot using monoclonal antibodies recognizing a linear or a conformational epitope on the RABV-G $[12,18]$. The correct size of the proteins (approx. $60 \mathrm{kDa}$ ) was confirmed by SDS-PAGE analysis (Supplementary Fig. 1). Furthermore, recognition of the RABV-G in a native PAGE gel with an antibody against a conformational epitope indicated correct folding of the protein.

\subsection{Immunogenicity of candidate vaccines}

The RABV-mG protein was immunogenic in NIH Swiss-albino mice when given in $10 \mu \mathrm{g} /$ mouse doses after two vaccinations. The lower doses of the RABV-mG protein ( $1 \mu \mathrm{g}$ and $3 \mu \mathrm{g}$ doses) were poorly immunogenic with borderline detectable ELISA and VNA antibody titers on the day of challenge (Fig. 1 and Table 1). However, addition of the Matrix- $\mathrm{M}^{\mathrm{TM}}$ adjuvant significantly increased immunogenicity (as measured with VNA titers) of the RABV-mG

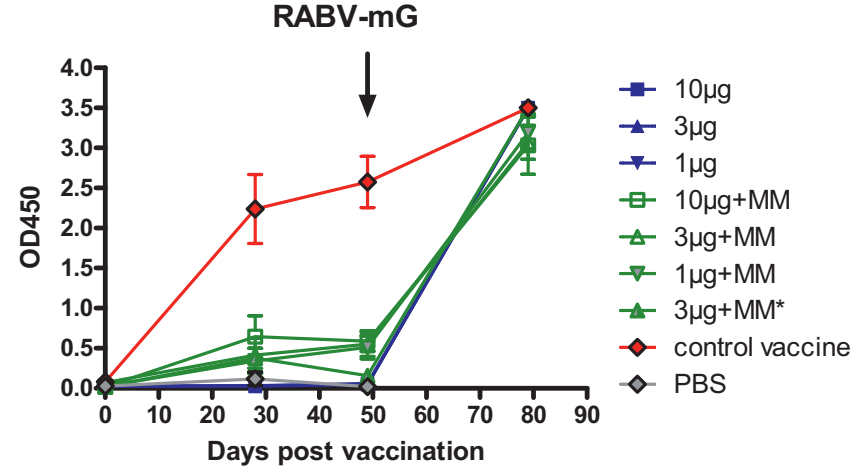

RABV-tG

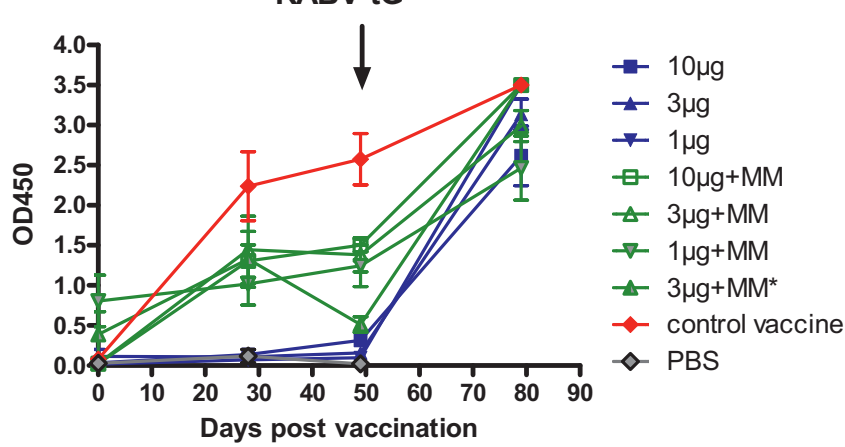

Fig. 1. Antibody responses measured by ELISA in mice ( $n=10$ /group) immunized with the RABV-mG (upper panel) or the RABV-tG (lower panel) candidate vaccines. Arrows indicate the day of challenge (day 49 post immunization). Positive (control vaccine) and negative (PBS) control groups are depicted in both panels for comparative purposes. Mean and standard error of the mean are depicted for each group. MM: Matrix-M $\mathrm{M}^{\mathrm{TM}} .3 \mu \mathrm{g}+\mathrm{MM}^{*}$ : group received one immunization on day 0 .

protein especially for the $3 \mu \mathrm{g}$ and $1 \mu \mathrm{g}$ doses $(p=0.0007, p<0.0001$ and $p=0.0001$ for the $10 \mu \mathrm{g}, 3 \mu \mathrm{g}$ and $1 \mu \mathrm{g}$ doses, respectively). Mice that had received only a single dose of $3 \mu \mathrm{g}$ of RABV-mG with Matrix-M ${ }^{\mathrm{TM}}$ developed VNA GMT's of $7.92 \mathrm{IU} / \mathrm{ml}$ (Table 1 ).

Immunogenicity of the RABV-tG protein was superior in $\mathrm{NIH}$ Swiss-albino mice compared to the RABV-mG protein given at the same concentrations. All animals developed antibodies after a single immunization with the respective doses of the RABV-tG protein (Fig. 1). These antibody titers were (significantly) boosted 
after second vaccination ( $p=0.0288, p=0.1431$ and $p=0.0232$ for the $10 \mu \mathrm{g}, 3 \mu \mathrm{g}$ and $1 \mu \mathrm{g}$ doses, respectively). All animals had high VNA titers on the day of challenge with GMT's of 11.35, 9.61 and $1.99 \mathrm{IU} / \mathrm{ml}$ for the $10 \mu \mathrm{g}, 3 \mu \mathrm{g}$ and $1 \mu \mathrm{g}$ dose, respectively (Table 1 ). The addition of Matrix-M $\mathrm{M}^{\mathrm{TM}}$ to the vaccine preparation further increased the immunogenicity of the RABV-tG protein as shown by the increased VNA GMT's in the respective groups $(13.03,13.40$ and $12.56 \mathrm{IU} / \mathrm{ml}$; Table 1 ). Also here, a single dose of $3 \mu \mathrm{g}$ of RABVtG protein with Matrix- $\mathrm{M}^{\mathrm{TM}}$ induced relatively high VNA titers in mice (GMT $10.16 \mathrm{IU} / \mathrm{ml}$ ).

VNA titers induced by both recombinant $G$ proteins were superior to those induced by the commercial vaccine used as a control (GMT 6.59 IU/ml; Table 1). The only exceptions were groups immunized with $3 \mu \mathrm{g}$ or $1 \mu \mathrm{g}$ of RABV-mG protein without adjuvant, which developed significantly lower VNA titers $(p=0.0312$ and $p=0.0002$, respectively; Mann-Whitney test).

\subsection{Maturation of immune response}

We also investigated the quality of the antibody response that the respective recombinant proteins induced using antibodyavidity maturation as a marker (Fig. 2). Both RABV-mG and RABV-tG induced antibodies of relatively high avidity. The addition of Matrix- $\mathrm{M}^{\mathrm{TM}}$ to the vaccine preparation further increased antibody avidity. Interestingly, there was a significant increase in the avidity index of the antibodies induced by RABV-mG and RABV-tG (Groups $3 \mu \mathrm{g}+\mathrm{MM}^{*}$ in Fig. $2 \mathrm{~A}$ and $\mathrm{B}$, respectively) after a single dose of the recombinant proteins adjuvanted with Matrix- $\mathrm{M}^{\mathrm{TM}}(p=0.007$ and $p=0.04$, respectively). Taken into consideration that high avidity antibodies correlate with increased longevity [19,20], these results indicate that the adjuvant used has the potential to induce longerlasting antibody responses in immunized mice.

\subsection{Protective efficacy of candidate vaccines}

All challenge control animals (mock immunized with PBS or Matrix-M $\mathrm{M}^{\mathrm{TM}}$ only) succumbed to rabies infection after 6 to 7 days post intracranial CVS-11 challenge. Mice succumbing to rabies showed typical signs of rabies including raffled haired, hunched-back posture, lethargy and hind-leg paralysis. Protection of immunized mice after this lethal challenge correlated well with the induced antibody titers. Only $10 \%$ of mice that received the lowest dose of RABV-mG survived lethal challenge whereas addition of Matrix- $\mathrm{M}^{\mathrm{TM}}$ to the vaccine preparation increased survival within the respective groups considerably, up to $90 \%$ (Fig. 3 and Table 1). RABV-tG protein with or without adjuvant conferred $100 \%$ protection against the lethal challenge irrespective of the dose, even after a single immunization with $3 \mu \mathrm{g}$ of protein adjuvanted with Matrix$\mathrm{M}^{\mathrm{TM}}$ (Table 1). As expected, the commercial vaccine that was used as a control in this study also protected $100 \%$ of the immunized mice.

Infectious virus was recovered from the brains of all animals that died of rabies encephalitis (Fig. 4A). Mice that had been immunized with non-protective doses of RABV-mG protein had lower titers in their brains compared to PBS or Matrix-M ${ }^{\mathrm{TM}}$ only controls $(p=0.001)$. Interestingly, at 28 days post challenge, viral RNA was still detectable in the majority of the animals that had survived challenge, including animals that had received the control vaccine. Viral RNA titers in surviving animals were lower than in animals that died of rabies encephalitis, the lowest being detected in the animals that had received either of the adjuvanted candidate vaccines (Fig. 4B). Attempts to recover infectious virus from surviving animals that were positive for viral RNA were not successful. Neither was detection of viral antigen by means of immunohistochemistry in the brains of animals that had a positive RNA result (data not shown). The significance and mechanism underlying these
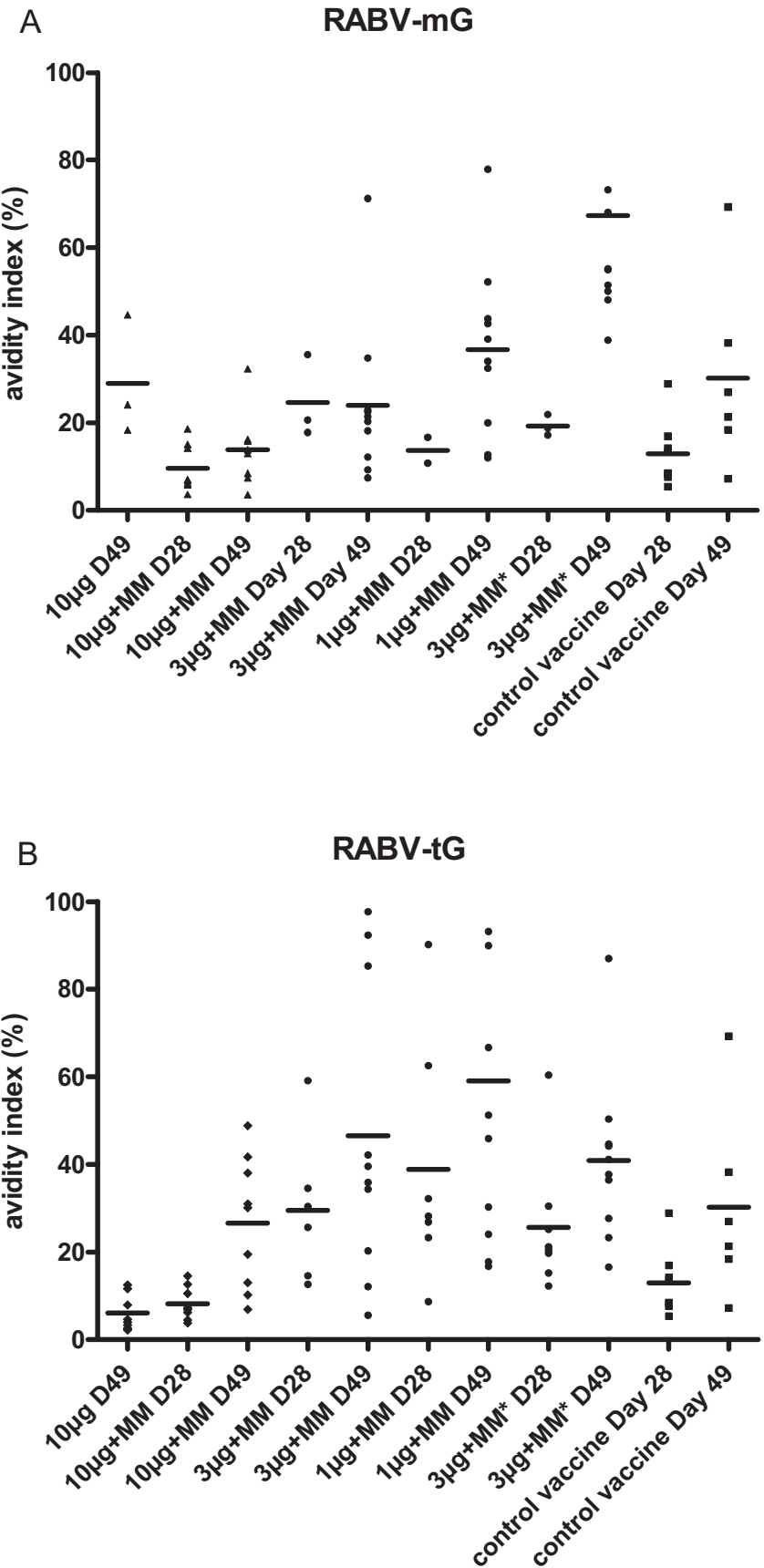

Fig. 2. Avidity index of antibodies measured by ELISA on days 28 and 49 post immunization in mice that received RABV-mG (panel A) or RABV-tG (panel B). MM: Matrix-M ${ }^{\mathrm{TM}} .3 \mu \mathrm{g}+\mathrm{MM}^{*}$ : group received one immunization on day 0 .

findings should be further analysed but the vaccine induced immunity is apparently sufficient to protect against lethal disease although apparently not sufficient to completely abolish RABV replication.

\section{Discussion}

In the present study we have used a novel approach to produce recombinant vaccine candidates against rabies and compared this with the more traditional approach. We have selected the $G$ protein of RABV that is known to induce VNAs and expressed it either in a baculovirus system as RABV-mG or in its more native trimeric form (RABV-tG) to increase immunogenicity. We have found that 
RABV-mG

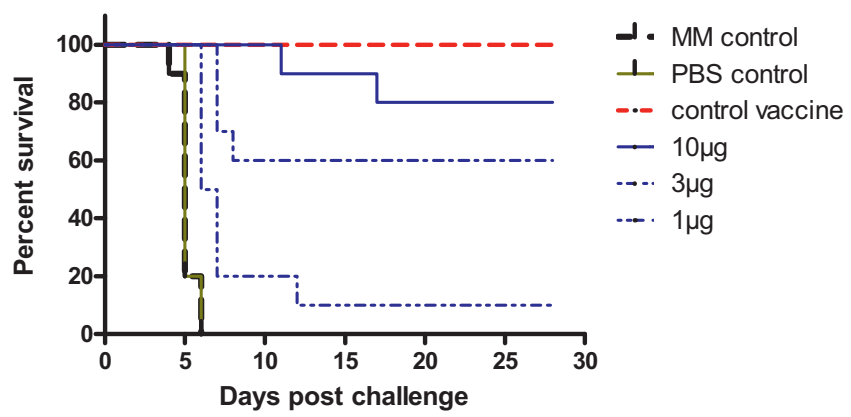

RABV-mG

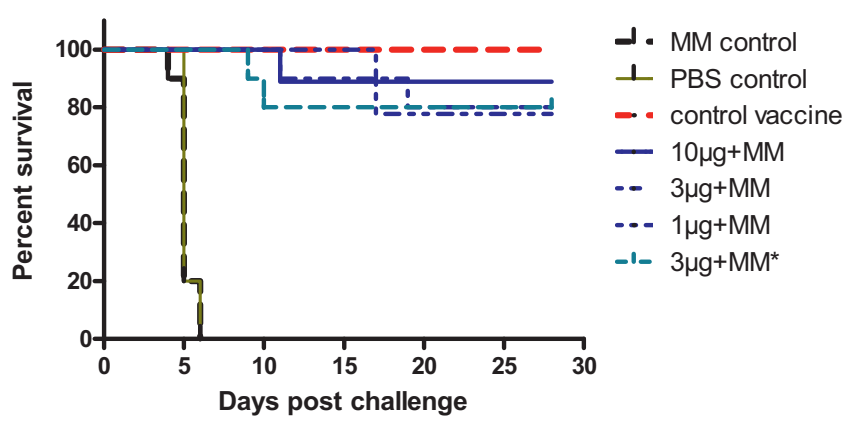

Fig. 3. Survival curves of mice immunized i.m. with the respective doses of baculovirus expressed RABV-mG without (upper panel) and with (lower panel) adjuvant and challenged i.c. with a lethal dose of CVS-11 49 days post immunization. Positive (control vaccine) and negative (PBS and Matrix-M $\mathrm{M}^{\mathrm{TM}}$ ) control groups are depicted in both panels for comparative purposes. MM: Matrix-M ${ }^{\mathrm{TM}} .3 \mu \mathrm{g}+\mathrm{MM}^{*}$ : group received one immunization on day 0 .

low doses of the RABV-tG are sufficient to induce potent and protective antibody response in outbred mice. Immunogenicity and efficacy of RABV-tG were superior to the RABV-mG produced with the baculovirus system. In addition, a potent adjuvant improved the level and quality of the RABV specific antibody response.

Despite rabies being a vaccine-preventable disease, it continues to be a public health problem for many RABV endemic countries as well as a serious threat to travellers to these countries. Vaccination of wild, feral and domesticated carnivores is currently the best option to control and prevent human rabies, as vaccination of humans is largely limited to groups at high-risk of exposure for financial reasons. Pre-exposure immunization schemes to prevent rabies are based on multi-dose regimens of killed whole virus vaccines. This approach, although highly effective for pre-exposure, has several disadvantages. For example, growing live virus to high titers requires high biosafety level laboratories. Inactivation is required before release of the vaccine batch and safety testing of every batch before release requires large numbers of laboratory animals. In addition, these vaccines require high and multiple doses in order to reach sufficiently high neutralizing antibody levels and protection. The need for new generation vaccines that confer long lasting protection at low cost using lower and fewer doses of viral antigen is evident and consequently advantages of using recombinant proteins for this purpose would be obvious for several reasons [6].

We have used recombinant technology to produce the RABV glycoprotein $G$, against which virus neutralizing antibodies are directed. We used both insect and mammalian expression systems to produce the monomeric and trimeric forms of the rabies glycoprotein $\mathrm{G}$, respectively. Both expression systems are known to preserve the protein's antigenic structure. Slightly different protein

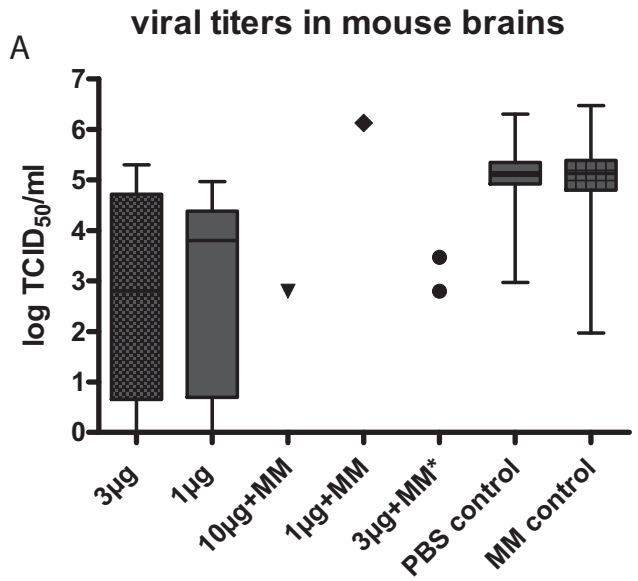

viral RNA in mouse brains

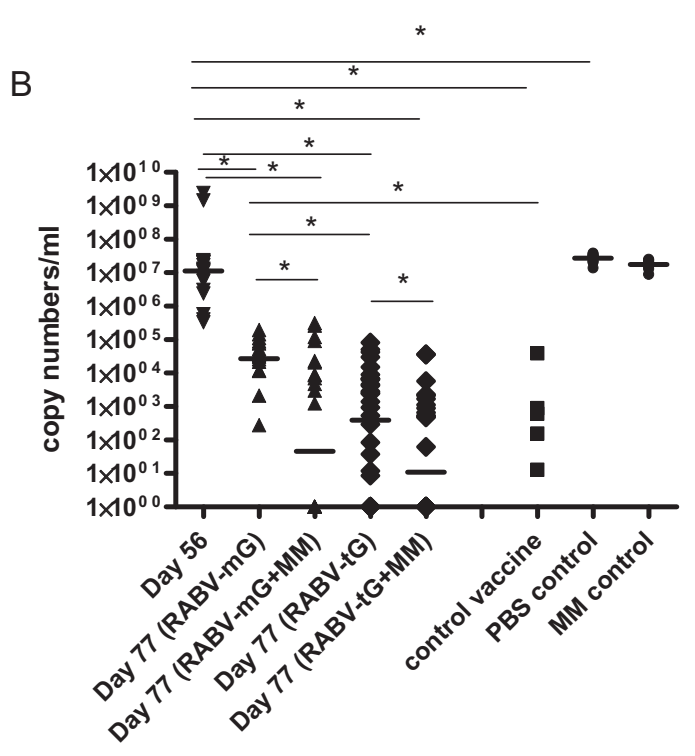

Fig. 4. RABV recovered from mice challenged with a lethal dose of CVS-11 49 days post immunization. (A) Infectious virus was only recovered from challenge control mice (PBS and Matrix-M ${ }^{\mathrm{TM}}$ ) and mice that were immunized with RABV-mG and died within one week after challenge. (B) Viral RNA was detected in the brain of mice that either died of rabies within one week post challenge (Day 56) or were euthanized 28 days post challenge (Day 77) without developing rabies. Black lines indicate the geometric mean within the group. Asterisks indicate significant differences between the groups ( $p<0.05$; Mann-Whitney test). MM: Matrix-M ${ }^{\mathrm{TM}} .3 \mu \mathrm{g}+\mathrm{MM}^{*}$ : group received one immunization on day 0 .

sizes were observed for the two expression systems (Supplementary Fig. 1) most likely reflecting the differences in glycosylation of proteins between insect and mammalian host cells. Baculovirus expressed recombinant proteins have been used for several candidate vaccines including RABV with promising results [7,21,22]. In the present study we have shown that baculovirus expressed RABV$\mathrm{mG}$ is relatively easy and inexpensive to produce although it still induces relatively limited protective antibody responses. To solve this problem, we have chosen to explore two approaches. First, we expressed the $G$ protein in its native trimeric form (RABV-tG) and showed that this protein complex is more immunogenic conferring complete protection at relatively low doses. It has been shown for HIV-1 and influenza that recombinant proteins expressed as native, multimeric proteins significantly increase the potency of candidate vaccines $[10,23,24]$. It is possible that multimers retain the native protein conformation and therefore present multiple relevant 
epitopes to B cells inducing a broader and more potent immune response [25]. Second, we explored the potential of adding a novel adjuvant formulation. Adjuvants are commonly used to increase quantity and quality of the immune response. Here we have chosen to use Matrix-M $\mathrm{M}^{\mathrm{TM}}$ a saponin-based adjuvant shown to stimulate both humoral and cellular immune responses [26]. The same adjuvant is currently in use for veterinary vaccines and has been tested in Phase I studies in humans for candidate influenza vaccines $[27,28]$. The addition of Matrix- $\mathrm{M}^{\mathrm{TM}}$ resulted in dose sparing and reduction of the number of doses needed for both preparations. The increase in the immunogenicity of RABV-mG was more apparent than the effect on the immunogenicity of the RABV-tG candidate vaccine (Table 1 and Fig. 3), which already performed better in a quantitative sense. However, Matrix- $\mathrm{M}^{\mathrm{TM}}$ was also shown to improve the quality of the immune response as demonstrated by the increased antibody avidity index in all mice receiving a vaccine formulation with Matrix- $\mathrm{M}^{\mathrm{TM}}$. This quantitative and qualitative effects leading to increased antibody and protective responses, may also lead to increased memory $B$ and $T$ cell responses which may in turn lead to better longevity of the protective efficacy elicited by the candidate vaccines tested. For rabies vaccines not only antigen sparing is a major issue, but also the longevity of the induced protective response. The effect of the addition of Matrix- $\mathrm{M}^{\mathrm{TM}}$ on longevity of antibody and protective responses as well as on the induction of specific $\mathrm{T}$ cell responses remains to be studied in more detail.

Despite the high efficacy of the candidate vaccines tested here, viral RNA was still detectable in the majority of the mice surviving lethal challenge with CVS-11 (Fig. 4B). Animals from all vaccinated groups (including the control-vaccine group) had detectable viral RNA even 28 days post challenge. It is known that RABV can persist in infected mice for long periods of time [29], although the mechanisms underlining this observation are not well understood. It was proposed that the nucleocapsid has a stabilizing effect on the viral genome, which allows persistence of the genome in the brain $[29,30]$. It could also mean that virus particles are taken up by supporting cells of the nervous system (e.g. microglia), which do not support viral replication but allow for persistence of viral genome for longer periods of time.

Taken together, the data presented here provide evidence that in mice both the trimeric presentation of the RABV G protein and the addition of Matrix- $\mathrm{M}^{\mathrm{TM}}$ not only lead to dose sparing but also to a qualitatively better immune response of vaccine candidates based on recombinant RABV-G proteins. This may pave the way toward the development of cheaper and qualitatively better rabies vaccine that provides longer protection with fewer vaccine doses in humans and animals.

\section{Conflict of interest statement}

The authors declare a conflict of interest.

\section{Acknowledgements}

The authors would like to acknowledge the efforts of Wafaa Mahmoud and Yoshi Hashimoto, both employees and shareholders of Protein Sciences Corporation and Angela Gomersbach for excellent technical assistance with mouse immunizations.

A.D.M.E. Osterhaus, Prof. Dr. (Ab) Department of Viroscience, Erasmus MC. a.osterhaus@erasmusmc.nl Phone: +31 107044066 Apart from heading the Department of Viroscience at the Erasmus MC, Prof. A.D.M.E. Osterhaus, DVM PhD is also involved in or with many other initiatives within the Virology field. This involvement ranges from expert advice to various international organisations involved in the area of general human and veterinary health to advising spin-out companies of the Erasmus University Medical Center Rotterdam that are endeavouring to bridge the gap between scientific discovery/knowledge and putting these to practical use in society. For purposes of transparency and to avoid of possible conflicts of interest, Professor Osterhaus discloses all his interests in matters related, directly or indirectly, to his position as head of the Department of Viroscience of Erasmus MC. Employment: * Professor of Virology at the Erasmus University Medical Center Rotterdam. \& Professor of Wildlife Virology and virus discovery at the University Utrecht. \& CEO of Artemis BV. Member of the Board of Directors of Protein Sciences Corporation US. \& Chairman of ESWI. \&astwissenschaftler an der Stiftung Tierärztliche Hochschule Hannover. \& Co-founder of MUGAS Foundation. Consultancy: Professor Osterhaus performs no consultancies or other interactions with companies on a personal title. Any consultancies or interactions he may perform, are through contracts between Erasmus MC or Artemis on the one hand and any companies that desire consulting services of professor Osterhaus on the other hand. Professor Osterhaus is a consultant to ViroClinics Biosciences B.V., Rotterdam. ViroClinics Biosciences B.V. a contract research organization that collaborates with pharmaceutical companies. Shareholder ownership: Professor Osterhaus has share certificates in ViroClinics Biosciences B.V. The majority of the shares in ViroClinics Biosciences BV (> 75\%) are owned by Erasmus MC through its Erasmus MC Holding B.V. To avoid any possible conflict of interest and to safeguard its employees against the possibility of unethical decisions, the Erasmus MC does not allow any of its employees to hold shares in person in any companies that are (partly) owned by Erasmus MC. As a result thereof, any shares provided by such companies to any Erasmus MC employees, are held by a Foundation Administration Office. The board of this foundation is appointed by Erasmus MC. The employees receive share certificates of their shares. Public Advisory Work: • WHO, Director Collaborating Centre for Arboviruses and Haemorrhagic Fever Reference and Research. • (Dutch) National Influenza Centre (NIC), Director. • EC, Member of the Task Force Vaccines and Viral Diseases. $\bullet$ EC, Member of the EC Scientific Steering Committee, ad hoc group on TSE/BSE. - WHO, Member Strategic Advisory Group of Experts (SAGE). • WHO, Member of the International Health Regulations (2005), roster of Experts. • WHO, Member of the SARS aetiology network. • WHO, Product development for aerosol measles vaccines. • Jenner Institute, Member of the International Scientific Advisory Board. - European Research Council Panel (ERC), Chair Advanced Grant Panel LS6: Immunity and Infection. • (British) Department for Environment, Food and Rural Affairs, Member of the Scientific Advisory Council Sub Group for Epidemic Diseases. • European Centre for Diseases Prevention and Control, roster of Scientists. • Dutch Food and Consumer Product Safety Authority, roster of scientists. • Council of Europe, European Pharmacopoeia Commission, Ad hoc working group "Quality of biologicals obtained from warm blood animals". - AIDS fund, Scientific Advisory Council. • European Parliament, Member Temporary Committee on Foot and Mouth Disease. $\bullet$ Dutch Health Council, advisor.

Manon Cox and Rick Chubet are employees and shareholders of Protein Sciences Corporation.

\section{Appendix A. Supplementary data}

Supplementary data associated with this article can be found, in the online version, at http://dx.doi.org/10.1016/j.vaccine. 2014.06.058.

\section{References}

[1] WHO. WHO expert consultation on rabies. World Health Organ Tech Rep Ser 2005;931:1-88 (back cover). 
[2] WHO. Rabies vaccines: WHO position paper-recommendations. Vaccine 2010;28(44):7140-2.

[3] Hicks DJ, Fooks AR, Johnson N. Developments in rabies vaccines. Clin Exp Immunol 2012;169(3):199-204.

[4] Gaudin Y, Ruigrok RW, Tuffereau C, Knossow M, Flamand A. Rabies virus glycoprotein is a trimer. Virology 1992;187(2):627-32.

[5] Ashraf S, Singh PK, Yadav DK, Shahnawaz M, Mishra S, Sawant SV, et al. High level expression of surface glycoprotein of rabies virus in tobacco leaves and its immunoprotective activity in mice. J Biotechnol 2005;119(1):1-14.

[6] Dietzschold B, Faber M, Schnell MJ. New approaches to the prevention and eradication of rabies. Expert Rev Vaccines 2003:2(3):399-406.

[7] Huang H, Xiao S, Qin J, Jiang Y, Yang S, Li T, et al. Construction and immunogenicity of a recombinant pseudotype baculovirus expressing the glycoprotein of rabies virus in mice. Arch Virol 2011;156(5):753-8.

[8] Kaur M, Saxena A, Rai A, Bhatnagar R. Rabies DNA vaccine encoding lysosometargeted glycoprotein supplemented with Emulsigen-D confers complete protection in preexposure and postexposure studies in BALB/c mice. FASEB J 2010:24(1):173-83.

[9] Li J, Faber M, Papaneri A, Faber ML, McGettigan JP, Schnell MJ, et al. A single immunization with a recombinant canine adenovirus expressing the rabies virus $G$ protein confers protective immunity against rabies in mice. Virology 2006;356(1-2):147-54, 5-20.

[10] Bosch BJ, Bodewes R, de Vries RP, Kreijtz JH, Bartelink W, van Amerongen G, et al. Recombinant soluble, multimeric HA and NA exhibit distinctive types of protection against pandemic swine-origin $2009 \mathrm{~A}(\mathrm{H} 1 \mathrm{~N} 1)$ influenza virus infection in ferrets. J Virol 2010;84(19):10366-74.

[11] Li W, Moore MJ, Vasilieva N, Sui J, Wong SK, Berne MA, et al. Angiotensinconverting enzyme 2 is a functional receptor for the SARS coronavirus. Nature 2003;426(6965):450-4

[12] Bunschoten H, Gore M, Claassen IJ, Uytdehaag FG, Dietzschold B, Wunner $\mathrm{WH}$, et al. Characterization of a new virus-neutralizing epitope that denotes a sequential determinant on the rabies virus glycoprotein. J Gen Virol 1989 Feb;70(Pt 2):291-8

[13] Wilbur LAaA MFA. The NIH potency test. In: Meslin FX, Kalpan MM, Koprowski $\mathrm{H}$, editors. Laboratory techniques in rabies. 4th ed. Geneva: World Health Organization; 1996.

[14] Cliquet F, Aubert M, Sagne L. Development of a fluorescent antibody virus neutralisation test (FAVN test) for the quantitation of rabies-neutralising antibody. J Immunol Methods 1998;212(1):79-87.

[15] Wakeley PR, Johnson N, McElhinney LM, Marston D, Sawyer J, Fooks AR. Development of a real-time, TaqMan reverse transcription-PCR assay for detection and differentiation of lyssavirus genotypes 1, 5, and 6. J Clin Microbiol 2005;43(6):2786-92.
[16] Koraka P, Martina BE, Roose JM, van Thiel PP, van Amerongen G, Kuiken T, et al In vitro and in vivo isolation and characterization of Duvenhage virus. PLoS Pathog 2012;8(5):e1002682.

[17] Kärber G. Beitrag zur behandlung kollektiver Reihenversuche. Arch Exp Patho Pharmakol 1931;162(4):480-3.

[18] Lafon M, Wiktor TJ, Macfarlan RI. Antigenic sites on the CVS rabies virus glycoprotein: analysis with monoclonal antibodies. J Gen Virol 1983;64(4): 843-51.

[19] Blink EJ, Light A, Kallies A, Nutt SL, Hodgkin PD, Tarlinton DM. Early appearance of germinal center-derived memory B cells and plasma cells in blood after primary immunization. J Exp Med 2005;201(4):545-54

[20] Slifka MK, Matloubian M, Ahmed R. Bone marrow is a major site of longterm antibody production after acute viral infection. J Virol 1995;69(3): 1895-902.

[21] Fu ZF, Rupprecht CE, Dietzschold B, Saikumar P, Niu HS, Babka I, et al. Ora vaccination of racoons (Procyon lotor) with baculovirus-expressed rabies virus glycoprotein. Vaccine 1993;11(9):925-8.

[22] Prehaud C, Takehara K, Flamand A, Bishop DH. Immunogenic and protective properties of rabies virus glycoprotein expressed by baculovirus vectors. Virology 1989;173(2):390-9.

[23] Li Y, Svehla K, Mathy NL, Voss G, Mascola JR, Wyatt R. Characterization of antibody responses elicited by human immunodeficiency virus type 1 primary isolate trimeric and monomeric envelope glycoproteins in selected adjuvants. J Virol 2006;80(3):1414-26.

[24] Sundling C, Forsell MN, O’Dell S, Feng Y, Chakrabarti B, Rao SS, et al. Soluble HIV 1 Env trimers in adjuvant elicit potent and diverse functional B cell responses in primates. J Exp Med 2010;207(9):2003-17.

[25] Yang X, Wyatt R, Sodroski J. Improved elicitation of neutralizing antibodies against primary human immunodeficiency viruses by soluble stabilized envelope glycoprotein trimers. J Virol 2001;75(3):1165-71.

[26] Reimer JM, Karlsson KH, Lovgren-Bengtsson K, Magnusson SE, Fuentes A, Stertman L. Matrix-M adjuvant induces local recruitment, activation and maturation of central immune cells in absence of antigen. PLoS One 2012;7(7):e41451.

[27] Cox RJ, Brokstad KA, Haaheim LR. Pandemic influenza vaccine development: time is of the essence. Expert Rev Vaccines 2006;5(5):603-6.

[28] Pedersen GK, Madhun AS, Breakwell L, Hoschler K, Sjursen H, Pathirana RD, et al. T-helper 1 cells elicited by H5N1 vaccination predict seroprotection. J Infect Dis 2012;206(2):158-66.

[29] Gomme EA, Wirblich C, Addya S, Rall GF, Schnell MJ. Immune clearance of attenuated rabies virus results in neuronal survival with altered gene expression. PLoS Pathog 2012;8(10):e1002971.

[30] Simon ID, van Rooijen N, Rose JK. Vesicular stomatitis virus genomic RNA persists in vivo in the absence of viral replication. J Virol 2010;84(7):3280-6. 